\title{
Compound feeds and cereals as potential tools for improved carp Cyprinus carpio production
}

\author{
David Hlaváč* , Jan Másílko, Maria Anton-Pardo, Pavel Hartman, Ján Regenda, \\ Pavel Vejsada, Jan Mráz, Zdeněk Adámek
}

\begin{abstract}
University of South Bohemia in Ceské Budějovice, Faculty of Fisheries and Protection of Waters, South Bohemian Research Centre of Aquaculture and Biodiversity of Hydrocenoses, Institute of Aquaculture and Protection of Waters, Na Sádkách 1780, 37005 Ceské Budějovice, Czech Republic
\end{abstract}

\begin{abstract}
Appropriate supplementary feeding is of increasing importance in common carp Cyprinus carpio pond aquaculture, not only with respect to production issues but also as a sustainable tool for maintaining environmental quality. We studied the effect of different supplementary feeding regimes (no supplemental feed, cereal grains, pelleted feed, pelleted feed with lowered phosphorus content, and extruded feed) on growth performance, water quality, natural food availability, phosphorus budget, fish body composition and economic performance in 10 experimental ponds stocked with 3 yr old carp at a density of 363 fish ha $^{-1}$ over a 4 mo period. The type of supplementary feed had no significant influence on water variables, with the exception of lowphosphorus pelleted feed which increased conductivity $(\mathrm{p}<0.05)$. No significant differences were observed in zooplankton density. Harvested fish had significantly $(\mathrm{p}<0.05)$ higher dry matter content and considerably higher phosphorus content under all treatments compared with fish at the beginning of the experiment. The use of cereals and extruded feed improved carp growth, while the physical qualities of the feed (higher resistance to nutrient leaching) resulted in lower nutrient concentrations in effluent water. Profitability was increased with application of cereal grains and decreased with all pelleted and extruded feeds. Hence, the use of cereal grain feed generated higher economic and environmental benefits than selected pelleted and extruded feed.
\end{abstract}

KEY WORDS: Pelleted feed · Extruded feed · Pond aquaculture · Supplementary feeding · Carp pond environment

\section{INTRODUCTION}

Management of waste discharged from fish farms is of major concern for the further development of aquaculture (Naylor et al. 2000, Mente et al. 2006). A global need to minimise the negative environmental effects of aquacultural production methods has been recognised through increased emphasis on the ecological use and management of natural resources to ensure a sustainable industry (Chamberlain \& Rosenthal 1995, Satoh et al. 2003). The reduction of aquatic waste through the use of environmentally friendly fish feed is now an important topic in aquacultural research (Lall 1991, Sugiura et al. 2000, Jahan et al.

\footnotetext{
*Corresponding author: hlavac@frov.jcu.cz
}

2001). In particular, minimising phosphorus waste is considered a key factor in the environmental sustainability of freshwater aquacultural operations, as an excess of phosphorus can stimulate eutrophication and cause environmental degradation (Hua \& Bureau 2010).

Aquacultural production in the Czech Republic is characterised by semi-intensive farming in earth ponds. According to Adámek et al. (2012), this method is used for the vast majority of production in the Czech Republic, with common carp Cyprinus carpio as the main species farmed at around $88 \%$ of total fish yield. Other species cultured are Chinese carps (grass carp Ctenopharyngodon idella, bighead carp

(C) The authors 2016. Open Access under Creative Commons by Attribution Licence. Use, distribution and reproduction are unrestricted. Authors and original publication must be credited. 
Hypophthalmichthys nobilis and silver carp H. molitrix), together with traditional supplementary fish (tench Tinca tinca) and predatory species such as pike Esox lucius, zander Sander lucioperca, European catfish Silurus glanis and perch Perca fluviatilis, which are all produced in ponds. Under this system, the greatest percentage of carp growth increment $(60-65 \%)$ is achieved through consumption of natural food, such as zooplankton and zoobenthos, and around $35-40 \%$ is based on supplementary feeding using mainly raw whole cereals (Adámek et al. 2012). In the recent past, fertilisers were added to ponds to increase natural primary productivity; however, this has led to eutrophication and algal blooms in ponds and receiving waterbodies due to high nutrient loading. According to current Czech legislation (Act No. 254/2001 Coll. - 'the Water Act'), application of fertilisers to the pond environment is an increasing problem that should be avoided in the future. As a result, the use of supplementary feeding, despite also being controlled by water authorities, remains the only available tool for intensification of fish production. On the other hand, reducing feed costs is also important for the long-term sustainability of aquaculture (Marković et al. 2012).

Significant progress in fish nutrition has been achieved through the use of pelleted and extruded feeds. These dietary supplements have higher digestibility, resulting in a lower feed conversion ratio and a reduction in excessive outflow of nutrients into the production system (Hardy \& Barrows 2000). Recently, pelleted and extruded feeds have been shown to be very useful tools for salmonid aquaculture, with the feed being almost immediately consumed by the fish (e.g. Barrows et al. 2007). Compound feeds are now also used in carp nursery ponds and some carp cageculture units. In some countries, extruded and pelleted feeds are relatively widely used for carp aquaculture as they provide a higher level of weight gain (Ćirić et al. 2015), improve meat quality (Mráz et al. 2012, Trbović et al. 2013, Živić et al. 2014) and increase the abundance of natural food while lowering the abundance of nuisance cyanobacteria (Ćirić et al. 2015). Most studies dealing with compound feeds, however, have focused on the rearing of juvenile carp at high stocking densities (>1200 ind. ha ${ }^{-1}$; Rašković et al. 2013, 2016, Živić et al. 2014, Ćirić et al. 2015), with almost none having examined the rearing of marketable sized carp.

In this study, we assessed the influence of 4 different supplementary feeds (extruded feed, pelleted feed, pelleted feed with lowered phosphorus content, and cereal grains) on water quality, phosphorus budget, carp growth, production performance and economic profitability in a range of semi-intensive carp production ponds.

\section{MATERIALS AND METHODS}

This study was conducted in 10 rectangular concrete storage ponds (surface area $300 \pm 20 \mathrm{~m}^{2}$, mean $\pm \mathrm{SD} ; 48^{\circ} 59^{\prime} \mathrm{N}, 14^{\circ} 46^{\prime} \mathrm{E}$ ) owned by Třeboň Fisheries Ltd. (Czech Republic) between 15 May and 3 September 2013 (112 d). Before stocking, the experimental ponds were drained and dried. The ponds were then refilled with water from the 215 ha Svět pond located upstream. Depth was set at $1 \mathrm{~m}$, which provided a uniform pond volume of around $300 \mathrm{~m}^{3}$. The bottom of the storage ponds consisted of a thin sandy substrate with negligible occurrence of macrozoobenthos; hence natural food was restricted almost entirely to zooplankton (as a result, zoobenthos sampling was omitted). The ponds were stocked in May ( $1 \mathrm{~d}$ after the ponds were filled) at a density of 363 fish ha ${ }^{-1}$ with 3 yr old scaled common carp (Třeboň strain) with a mean $( \pm$ SD) individual weight of $920 \pm$ $83 \mathrm{~g}$ (corresponding to a biomass of approximately $334 \mathrm{~kg} \mathrm{ha}^{-1}$ ). This stocking pattern is typical for semiintensive carp culture in the Třebon̆ region as it allows for maintenance of a sufficient level of large zooplankton. All fish used in the study were of uniform genetic origin and of the same age. Each individual was marked with a microchip in the dorsal musculature using a DataMars Needle Kit with a simple implanter.

Fish in separate ponds were fed with 4 different types of supplementary feed: (1) triticale cereal grains (CG), (2) sinking pelleted feed with $12.5 \%$ protein $(\mathrm{PF}),(3)$ sinking pelleted feed with $12.5 \%$ protein and lowered phosphorus content (PFLP) and (4) sinking extruded feed with $24 \%$ protein (Aller Aqua Supplement) (EF). All feed mixtures have previously been used for supplementary feeding of marketsized common carp and are commonly used in Czech pond aquaculture. One additional group, which served as a control (C), received no supplementary feed, its diet being based exclusively on naturally occurring food. Each treatment was run in duplicate.

Fish were fed 3 times a week (Monday, Wednesday, Friday), with the feed placed in a concrete feeding pit from 08:00 to 09:00 $\mathrm{h}$ local time. The feed ration was equivalent to $2-3 \%$ of actual fish biomass adjusted to temperature, oxygen level and feed uptake. Thus, May, June, July, August and September doses comprised $5,25,35,30$ and $5 \%$ of the total feed, respec- 
tively. This way of supplemental feeding is frequently used in pond aquaculture in this region. The major objective was to regulate the amount of feed to achieve an amount providing similar levels of estimated digestible energy (DE) across all experimental groups, calculated according to Steffens (1989) as:

$$
\begin{aligned}
& \mathrm{DE}=0.0168 \times \text { protein }+0.0335 \times \text { fat } \\
& +0.0147 \times \text { nitrogen-free extract }
\end{aligned}
$$

The proximate composition of the supplements was analysed according to standard methods in a certificated laboratory (AOAC 1995). Samples were ovendried at $105^{\circ} \mathrm{C}$ for $24 \mathrm{~h}$ to determine dry matter and moisture content and burned in a muffle furnace $\left(550^{\circ} \mathrm{C}\right.$ for $\left.12 \mathrm{~h}\right)$ to determine ash content. Protein content $(\mathrm{N} \times 6.25)$ was estimated by the Kjeldahl method after acid digestion; lipids by petrol ether extraction in a Soxtec System HT; and fibre content by drying and ashing after the extraction with $0.5 \mathrm{M}$ $\mathrm{H}_{2} \mathrm{SO}_{4}$ and $0.5 \mathrm{M} \mathrm{NaOH}$. Calcium and phosphorus were analysed using an atomic emission spectrometry (Czech National Standard for feed analysis; CSN 467092 [1998]). Nitrogen-free extract was calculated by subtracting the sum percentage of crude protein, crude fiber, crude lipid and total ash from 100 (Table 1).

\section{Water quality analysis}

During the experiment, water quality parameters were determined monthly between 07:00 and 10:00 h local time. Water temperature, $\mathrm{pH}$, dissolved oxygen and conductivity were measured in situ using a YSI

Table 1. Chemical composition and consumption rate of feeds provided in the experiments. CG: cereal grains; PF: pelleted feed; PFLP: pelleted feed with lowered phosphorus content; EF: extruded feed; NFE: nitrogen-free extract; Ca: calcium;

\begin{tabular}{|c|c|c|c|c|}
\hline \multirow[t]{2}{*}{ Composition and DE } & \multicolumn{4}{|c|}{ - Treatment- } \\
\hline & $\mathrm{CG}$ & $\mathrm{PF}$ & PFLP & $\mathrm{EF}$ \\
\hline Dry matter $\left(\mathrm{g} \mathrm{kg}^{-1}\right)$ & 874 & 884 & 896 & 914 \\
\hline $\operatorname{Protein}^{\mathrm{a}}\left(\mathrm{g} \mathrm{kg}^{-1}\right)$ & 102 & 124.3 & 130.7 & 239 \\
\hline $\mathrm{Fat}^{\mathrm{a}}\left(\mathrm{g} \mathrm{kg}^{-1}\right)$ & 12.7 & 29.4 & 34.9 & 72.8 \\
\hline $\operatorname{NFE}^{\mathrm{a}}\left(\mathrm{g} \mathrm{kg}^{-1}\right)$ & 721.8 & 682.9 & 665.5 & 496.7 \\
\hline $\operatorname{Ash}^{\mathrm{a}}\left(\mathrm{g} \mathrm{kg}^{-1}\right)$ & 18.3 & 31.2 & 30.90 & 62.6 \\
\hline Fibre $^{\mathrm{a}}\left(\mathrm{g} \mathrm{kg}^{-1}\right)$ & 19.2 & 32.3 & 34.0 & 43.3 \\
\hline $\mathrm{Ca}^{\mathrm{a}}\left(\mathrm{g} \mathrm{kg}^{-1}\right)$ & 0.4 & 1.8 & 1.4 & 3.9 \\
\hline $\mathrm{TP}^{\mathrm{a}}\left(\mathrm{g} \mathrm{kg}^{-1}\right)$ & 3.39 & 5.12 & 4.35 & 7.27 \\
\hline $\mathrm{DE}\left(\mathrm{MJ} \mathrm{kg}^{-1}\right)$ & 12.75 & 13.11 & 13.16 & 13.76 \\
\hline $\begin{array}{l}\text { Total feed consumption } \\
\text { per pond }(\mathrm{kg})\end{array}$ & 31.35 & 30.5 & 30.4 & 29.07 \\
\hline Total DE per pond (MJ) & 399.7 & 399.9 & 400.1 & 400.0 \\
\hline${ }^{\mathrm{a}}$ Content in wet biomass & & & & \\
\hline
\end{tabular}

TP: total phosphorus; DE: estimated digestible energy
Professional Plus multimeter. A pooled water sample covering the whole water column (ca. $1 \mathrm{~m}$ ) was collected at each pond from 4 different locations (from each side of experimental pond) using a modified tube sampler (Opting Service). Four samples in each pond were pooled in a $10 \mathrm{l}$ container. Part of this sample was used to measure turbidity, using a WTW Turb 430T/SET, and alkalinity, determined by the titrimetric method. Water samples were stored in 21 bottles and kept at $4{ }^{\circ} \mathrm{C}$ until analysed in the laboratory.

Hydrochemical variables (i.e. ammonium nitrogen, nitrate nitrogen, total nitrogen, phosphate phosphorus, total phosphorus, total suspended solids, biochemical oxygen demand, chemical oxygen demand and chlorophyll a) were assessed according to accredited methods (see Hlaváč et al. 2015) in a certificated laboratory.

\section{Zooplankton sampling and analysis}

Zooplankton samples were taken using a $22 \mathrm{~cm}$ diameter plankton net ( $80 \mu \mathrm{m}$ mesh), which was towed along for $5 \mathrm{~m}$ from the monk (outlet) of the pond. Organisms retained in the net were preserved with $4 \%$ formaldehyde for later analysis in the laboratory, where several subsamples were later counted using a Sedgewick-Rafter cell in an inverted microscope.

\section{Fish growth and production}

Fish were harvested at the end of the experimental period (September). Each fish was weighed, and this was compared with measurements taken at the beginning of the experiment (i.e. in fish hereafter referred to as 'stocked fish') in order to assess individual growth performance over the rearing period.

Specific growth rate (SGR) was calculated as:

$$
\operatorname{SGR}\left(\% \mathrm{~d}^{-1}\right)=\left(\ln W_{\mathrm{T}}-\ln W_{0}\right) \times 100 / t
$$

where $W_{\mathrm{T}}$ is the final body weight $(\mathrm{kg}), W_{0}$ is the initial body weight $(\mathrm{kg})$ and $t$ is the culture period (days).

\section{Phosphorus budget}

In order to calculate the phosphorus budget, input via supplementary feed was first calculated as dry matter and total phosphorus, according to the Czech National Standard for feed analysis (CSN 46 7092, 1998). Fish phosphorus content was analysed for 25 
fish randomly selected during stocking and harvesting (5 fish from the stocking group and 4 fish from each treatment after harvesting). The fish were starved until the digestive tract was empty, whereupon each fish was mechanically killed (using a wooden mallet) and ground in a commercial food grinder (Seydelmann K40) 3 times for 3 min to ensure homogenisation. The samples were stored in a freezer until further analysis. After thawing, body composition was analysed according to Czech National Standards (CSN 46 7092, 1998). Dry matter was assessed by drying the samples to constant weight at $105^{\circ} \mathrm{C}$.

Phosphorus input (feed) was calculated as:

Phosphorus in feed $(\mathrm{g})=$ phosphorus concentration in feed

$\times$ total amount of feed supplied

Phosphorus input/output (fish) was calculated as:

Phosphorus in fish $(\mathrm{g})=$

phosphorus concentration in stock/

harvested fish carcasses $\times$ total fish biomass

For phosphorus budget in water, cumulative inputs immediately after pond refilling and outputs in the discharge water were calculated in relation to experimental pond volume.

\section{Economic evaluation}

Income and net profit were estimated using simple economic analysis. In each case, the estimate was based on local market retail prices of feed and fish in 2013 and converted into Euros ( $€$ ) at the average rate valid in 2013. These prices were set at $0.22 € \mathrm{~kg}^{-1}$ for cereal grains, $0.26 € \mathrm{~kg}^{-1}$ for pelleted feed and pellets with lowered phosphorus and $0.58 € \mathrm{~kg}^{-1}$ for extruded feed. Values for stocked 3 yr old carp and harvested marketable carp were set at $2.20 € \mathrm{~kg}^{-1}$ and $2.00 € \mathrm{~kg}^{-1}$, respectively.

\section{Data analysis}

All values were checked for normality of data distribution and homogeneity of variance using the Kolmogorov-Smirnov and Levene tests, respectively. Differences between treatments for zooplankton density and specific growth rate of fish were analysed using 1-way ANOVA, with statistical significance set at $\alpha=0.05$, and Tukey's post hoc test applied when differences were significant. In cases where the assumptions for ANOVA were not met, the non-parametric Kruskal-Wallis test was used, with the non-parametric multiple comparison test performed when results were significant (statistical significance set at $\alpha=0.05$ ). Differences between chemical composition of stocked and harvested fish were analysed using the non-parametric Mann-Whitney $U$-test. Data were processed using STATISTICA CZ v. 12 data analysis software (StatSoft CR).

\section{RESULTS}

\section{Water quality}

Average temperature remained within the optimal range for carp growth (mean $\pm \mathrm{SD}$ : $19.1 \pm 3.8^{\circ} \mathrm{C}$ ) throughout the experiment (Table 2). Similarly, dissolved oxygen also stayed within the recommended range for carp pond culture throughout, ranging from 7.02 to $7.56 \mathrm{mg} \mathrm{l}^{-1}$, with the highest mean value observed in the control ponds. The only variable that showed a significant difference between treatments was conductivity, which was significantly higher in the PFLP treatment ponds compared with the control $(\mathrm{p}<0.05$; Table 2). Nutrient concentration showed only minor variation between treatments, with no significant differences.

\section{Zooplankton}

No significant differences were found between treatments for any zooplankton group and no clear pattern was observed in group dominance for each treatment (Table 3), but the control treatment without supplemental feeding showed on average lower zooplankton rates, showing the stronger feeding pressure on these resources under these circumstances. Cladocerans were abundant in all ponds, with Bosmina longirostris and Chydorus sphaericus as the dominant species. In ponds receiving supplementary feed, cladocerans showed some changes over time. For example, while Daphnia longispina was the most abundant species in June and at the end of the study (September), it was replaced by smaller species (i.e. $B$. longirostris, $B$. coregoni, Ceriodaphnia spp. and C. sphaericus) on the other sampling dates (data not shown).

\section{Fish growth}

SGR values in ponds with supplementary feeding were significantly different $(p<0.05)$ from the control 
Table 2. Water quality variables (Kruskal-Wallis $H$-values and mean $\pm \mathrm{SD}$ ) in experimental carp Cyprinus carpio ponds under 5 different feeding regimes $(n=18$ samples; time $=112 \mathrm{~d}$ ). C: control (no supplementary feeding); CG: cereal grains; PF: pelleted feed; PFLP: pelleted feed with lowered phosphorus content; EF: extruded feed; T: water temperature; DO: dissolved oxygen; $\mathrm{O}_{2}$ Sat: oxygen saturation; TA: total alkalinity; $\mathrm{NH}_{4}-\mathrm{N}$ : ammonium nitrogen; $\mathrm{NO}_{3}-\mathrm{N}$ : nitrate nitrogen; TN: total nitrogen; $\mathrm{PO}_{4}$-P: phosphate phosphorus; TP: total phosphorus; $\mathrm{BOD}_{5}$ : biochemical oxygen demand $5 \mathrm{~d}$ test; $\mathrm{COD}_{\mathrm{Cr}}$ : chemical oxygen demand using potassium dichromate; TSS: total suspended solids; Chl $a$ : chlorophyll $a$. Superscripts a and b represent outcomes from the non-parametric multiple comparison test (Kruskal-Wallis and multiple comparison test). Mean values in the same row with different superscripts differ significantly $\left({ }^{*} \mathrm{p}<0.05\right)$

\begin{tabular}{|c|c|c|c|c|c|c|}
\hline \multirow{2}{*}{ Variable } & \multirow{2}{*}{$H$} & \multicolumn{5}{|c|}{-Treatment } \\
\hline & & $\mathrm{C}$ & $\mathrm{CG}$ & PF & PFLP & EF \\
\hline $\mathrm{T}\left({ }^{\circ} \mathrm{C}\right)$ & 0.67 & $18.7 \pm 3.6$ & $19.0 \pm 3.8$ & $19.1 \pm 3.9$ & $19.4 \pm 3.9$ & $19.1 \pm 3.9$ \\
\hline $\mathrm{DO}\left(\mathrm{mg} \mathrm{l}^{-1}\right)$ & 1.22 & $7.56 \pm 1.90$ & $7.04 \pm 1.57$ & $7.02 \pm 1.84$ & $7.21 \pm 1.34$ & $7.39 \pm 1.31$ \\
\hline $\mathrm{O}_{2}$ Sat. (\%) & 0.98 & $80.77 \pm 21.72$ & $76.12 \pm 16.65$ & $76.13 \pm 21.62$ & $80.26 \pm 12.94$ & $79.57 \pm 13.76$ \\
\hline $\mathrm{pH}$ & 0.88 & $8.13 \pm 0.52$ & $8.01 \pm 0.38$ & $8.10 \pm 0.49$ & $8.14 \pm 0.34$ & $8.10 \pm 0.46$ \\
\hline Conductivity $\left(\mu \mathrm{S} \mathrm{cm}^{-1}\right)$ & $12.60^{*}$ & $158.33 \pm 8.12^{\mathrm{a}}$ & $162.38 \pm 12.75$ & $169.71 \pm 15.0$ & $175.03 \pm 18.15^{\mathrm{b}}$ & $170.2 \pm 14.37$ \\
\hline Turbidity (NTU) & 4.67 & $15.39 \pm 8.09$ & $16.38 \pm 12.75$ & $14.16 \pm 10.41$ & $12.82 \pm 9.57$ & $11.02 \pm 9.31$ \\
\hline $\mathrm{TA}\left(\mathrm{mmol} \mathrm{l}^{-1}\right)$ & 4.21 & $1.11 \pm 0.17$ & $1.11 \pm 0.17$ & $1.23 \pm 0.27$ & $1.24 \pm 0.22$ & $1.20 \pm 0.25$ \\
\hline $\mathrm{NH}_{4}-\mathrm{N}\left(\mathrm{mg} \mathrm{l}^{-1}\right)$ & 8.23 & $0.03 \pm 0.05$ & $0.04 \pm 0.06$ & $0.03 \pm 0.06$ & $0.01 \pm 0.03$ & $0.01 \pm 0.02$ \\
\hline $\mathrm{NO}_{3}-\mathrm{N}\left(\mathrm{mg} \mathrm{l}^{-1}\right)$ & 9.16 & $0.03 \pm 0.02$ & $0.02 \pm 0.04$ & $0.01 \pm 0.01$ & $0.01 \pm 0.02$ & $0.01 \pm 0.02$ \\
\hline $\mathrm{TN}\left(\mathrm{mg} \mathrm{l}^{-1}\right)$ & 4.91 & $2.30 \pm 0.99$ & $2.45 \pm 1.60$ & $2.27 \pm 1.12$ & $1.77 \pm 0.72$ & $1.83 \pm 0.81$ \\
\hline $\mathrm{PO}_{4}-\mathrm{P}\left(\mathrm{mg} \mathrm{l}^{-1}\right)$ & 9.44 & $0.02 \pm 0.02$ & $0.03 \pm 0.06$ & $0.01 \pm 0.01$ & $0.01 \pm 0.01$ & $0.01 \pm 0.01$ \\
\hline $\mathrm{TP}\left(\mathrm{mg} \mathrm{l}^{-1}\right)$ & 1.75 & $0.21 \pm 0.08$ & $0.21 \pm 0.11$ & $0.20 \pm 0.10$ & $0.19 \pm 0.09$ & $0.18 \pm 0.08$ \\
\hline $\mathrm{BOD}_{5}\left(\mathrm{mg} \mathrm{l}^{-1}\right)$ & 6.73 & $8.06 \pm 2.28$ & $7.50 \pm 2.58$ & $7.91 \pm 3.02$ & $6.31 \pm 2.25$ & $6.72 \pm 2.51$ \\
\hline $\mathrm{COD}_{\mathrm{Cr}}\left(\mathrm{mg} \mathrm{l}^{-1}\right)$ & 4.09 & $80.68 \pm 19.98$ & $79.22 \pm 29.55$ & $79.82 \pm 26.05$ & $73.51 \pm 24.40$ & $69.68 \pm 18.58$ \\
\hline $\operatorname{TSS}\left(\mathrm{mg} \mathrm{l}^{-1}\right)$ & 3.22 & $29.77 \pm 12.86$ & $30.63 \pm 19.34$ & $27.82 \pm 17.16$ & $25.60 \pm 16.57$ & $22.85 \pm 15.40$ \\
\hline Chl a $\left(\mu \mathrm{g} \mathrm{l^{-1 }}\right)$ & 1.82 & $123 \pm 83$ & $102 \pm 65$ & $123 \pm 87$ & $110 \pm 88$ & $109 \pm 103$ \\
\hline
\end{tabular}

Table 3. Mean $( \pm \mathrm{SD})$ density (ind. $\mathrm{l}^{-1}$ ) of the main zooplankton groups in each treatment (see Table 2 )

\begin{tabular}{|c|c|c|c|c|c|}
\hline \multirow{2}{*}{$\begin{array}{l}\text { Zooplankton } \\
\text { group }\end{array}$} & & & \multirow{2}{*}{$\begin{array}{c}\text { - Treatment } \\
\text { PF }\end{array}$} & \multirow[b]{2}{*}{ PFLP } & \multirow[b]{2}{*}{$\mathrm{EF}$} \\
\hline & C & $\mathrm{CG}$ & & & \\
\hline Rotifers & $202.3 \pm 159.4$ & $223.4 \pm 202.1$ & $167.3 \pm 184.6$ & $186.4 \pm 148.6$ & $150.8 \pm 189.0$ \\
\hline Copepods & $159.3 \pm 87.8$ & $276.0 \pm 205.4$ & $263.3 \pm 192.8$ & $237.4 \pm 172.3$ & $253.6 \pm 139.7$ \\
\hline Cladocerans & $122.9 \pm 97.7$ & $275.1 \pm 424.3$ & $262.6 \pm 342.6$ & $141.0 \pm 173.8$ & $239.1 \pm 377.4$ \\
\hline
\end{tabular}

at the end of the experiment (Fig. 1). The CG and EF treatments produced significantly higher $(p<0.05)$ SGR values than the PF and PFLP treatments. No significant differences in SGR were recorded between PF and PFLP and between CG and EF.

\section{Fish chemical composition}

In all experimental ponds, harvested fish had significantly higher dry matter content than fish at the time of stocking (all $\mathrm{p}<0.05$; Table 4 ). In addition, harvested fish from the PFLP and EF treatment ponds had a significantly higher phosphorus content than stocked fish. There was no significant difference between treatments regarding phosphorus concentration in harvested fish.

\section{Phosphorus budget}

Phosphorus budget (calculated as the increase of phosphorus in fish biomass minus input of phosphorus in the feed) was significantly higher in the control pond (with zero feed input) than in the CG treatment ( $p<0.05$; Table 5). The PF, PFLP and EF treatment ponds had significantly lower budget values than the other treatments $(p<0.05)$. Phosphorus concentrations in inflow and outflow waters indicated a release of phosphorus in all ponds, including the control ponds, with effluent water having higher phosphorus than inflow water. Phosphorus budget (in inflow and effluent water) from the control was significantly lower than that for the PFLP treatment $(p<0.05)$. The highest phosphorus loading in effluent water (though not significantly so) was observed for the PFLP and 


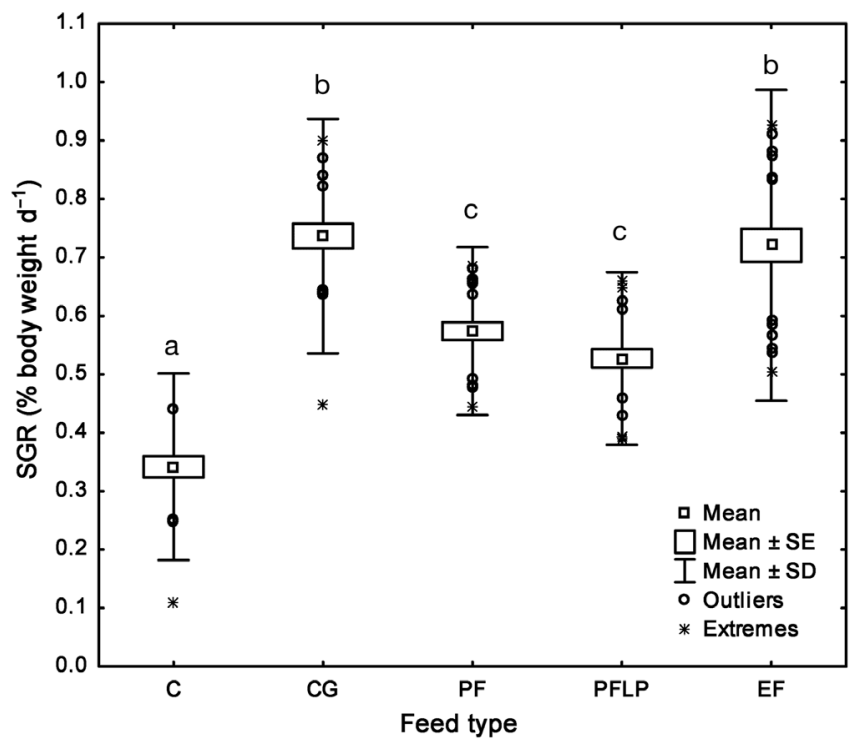

Fig. 1. Specific growth rate (SGR) of common carp Cyprinus carpio (means and $\mathrm{SD}, \mathrm{n}=22$ ) calculated for different supplementary feeding treatments after $112 \mathrm{~d}$. Treatments with different letters are significantly different $(p<0.05)$ according to Tukey's post hoc test. C: control without supplementary feed; CG: cereal grains; PF: pelleted feed; PFLP: pelleted feed with lowered phosphorus content; ET: extruded feed
PF treatments. The final budget for phosphorus input and output suggests a possible unexplored secondary source of phosphorus for all treatments.

\section{Economic evaluation}

Economic analysis indicated that net profit increased with the application of CG and declined when using PF, PFLP and EF feeds (Table 6). Even the control pond, which received no supplementary feed, showed higher profitability than some treatments with PFLP and EF feed. Significant differences were only observed between the CG and PFLP treatments; however, due to the high variability between replicates.

\section{DISCUSSION}

As a rule, pond management practice is generally assumed to have a strong impact on water quality, and particularly as a source of nutrients (Rahman et al. 2008, Rahman 2015). In our study, however, we

Table 4. Chemical composition (mean \pm SD) of carp Cyprinus carpio at stocking and harvesting. Treatments as in Fig. 1. Superscripts a and b represent outcomes from the non-parametric Mann-Whitney $U$-test between stocked and harvested fish. Mean values in the same column with different superscripts differ significantly $(p<0.05)$

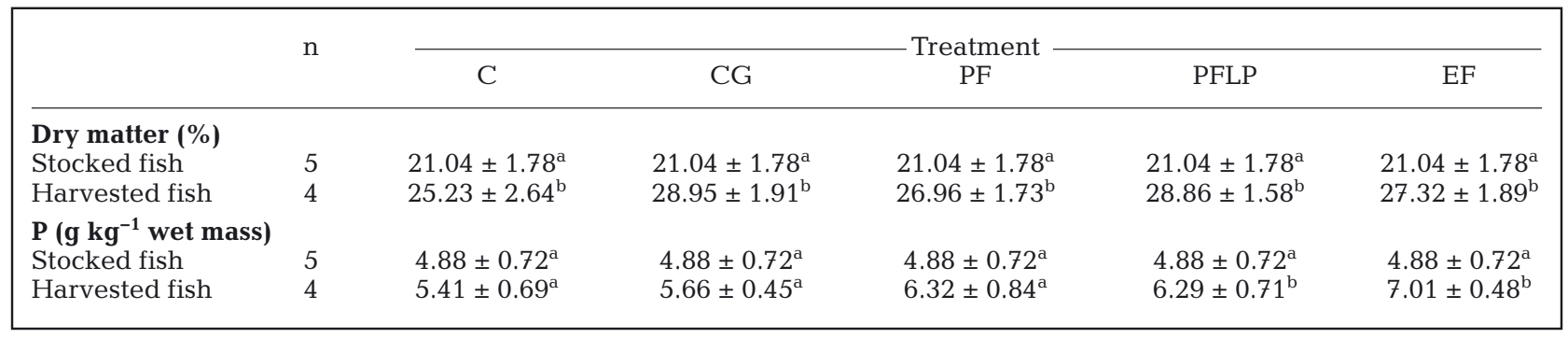

Table 5. Mean $( \pm \mathrm{SD})$ phosphorus budget $(\mathrm{g})$ for carp Cyprinus carpio yield and for inflow and effluent water under different treatments (see Fig. 1) per experimental storage pond. Superscripts a, b and c represent outcomes from the non-parametric multiple comparison test (Kruskal-Wallis and multiple comparison test). Mean values in the same row with different superscripts differ significantly $(\mathrm{p}<0.05)$

\begin{tabular}{|c|c|c|c|c|c|}
\hline & $\mathrm{C}$ & CG & PF & PFLP & EF \\
\hline Stocked fish & $39.33 \pm 4.71$ & $46.1 \pm 0.1$ & $45.44 \pm 1.22$ & $45.75 \pm 0.11$ & $45.02 \pm 1.05$ \\
\hline Feed & - & $106.3 \pm 0.0$ & $156.2 \pm 0.0$ & $132.2 \pm 0.0$ & $211.3 \pm 0.0$ \\
\hline Harvested fish & $70.42 \pm 14.95$ & $133.71 \pm 25.22$ & $121.56 \pm 3.93$ & $115.61 \pm 5.88$ & $156.34 \pm 19.67$ \\
\hline Budget & $31.09 \pm 10.2^{\mathrm{a}}$ & $-18.69 \pm 25.21^{b}$ & $-80.08 \pm 5.15^{c}$ & $-62.34 \pm 6.0^{c}$ & $-99.98 \pm 20.72^{\mathrm{c}}$ \\
\hline Inflow water & $47.31 \pm 1.76$ & $51.26 \pm 2.09$ & $48.95 \pm 1.28$ & $49.88 \pm 6.01$ & $50.01 \pm 0.06$ \\
\hline Effluent water & $65.84 \pm 0.47$ & $83.92 \pm 11.50$ & $92.07 \pm 8.65$ & $102.72 \pm 13.97$ & $81.59 \pm 19.16$ \\
\hline Budget & $18.53 \pm 2.24^{\mathrm{a}}$ & $32.66 \pm 9.42^{\mathrm{ab}}$ & $43.12 \pm 9.92^{\mathrm{ab}}$ & $52.84 \pm 19.98^{\mathrm{b}}$ & $31.58 \pm 19.10^{\mathrm{ab}}$ \\
\hline
\end{tabular}


Table 6. Cost analysis (in $€ \mathrm{ha}^{-1}$ ) of common carp Cyprinus carpio culture using different feeds. C: control without supplementary feed; CG: cereal grains; PF: pelleted feed; PFLP: pelleted feed with lowered phosphorus content; ET: extruded feed. Superscripts a and b represent outcomes from the non-parametric multiple comparison test (Kruskal-Wallis and multiple comparison test). Mean values in the same row with different superscripts differ significantly $(\mathrm{p}<0.05)$

\begin{tabular}{|c|c|c|c|c|c|}
\hline & $\mathrm{C}$ & CG & $\mathrm{PF}$ & PFLP & $\mathrm{EF}$ \\
\hline Cost of fish stock & $713 \pm 20$ & $713 \pm 10$ & $724 \pm 14$ & $724 \pm 14$ & $709 \pm 15$ \\
\hline Cost of feed & - & $218 \pm 3$ & $262 \pm 3$ & $257 \pm 8$ & $538 \pm 2$ \\
\hline Total cost & $713 \pm 20$ & $932 \pm 13$ & $986 \pm 17$ & $981 \pm 22$ & $1248 \pm 16$ \\
\hline Income (fish sales) & $966 \pm 116$ & $1486 \pm 141$ & $1269 \pm 24$ & $1197 \pm 68$ & $1460 \pm 187$ \\
\hline Net profit & $253 \pm 95$ & $555 \pm 154^{\mathrm{a}}$ & $283 \pm 7$ & $216 \pm 45^{\mathrm{b}}$ & $212 \pm 203$ \\
\hline
\end{tabular}

found that supplementary feeding with compound feeds and cereals had no significant effect on nutrient concentrations in the water or on water variables, aside from conductivity. Previous studies (e.g. Hlaváč et al. 2015) have also observed no significant difference in water quality between carp ponds with and without supplementary feeding. Furthermore, Dulić et al. (2010) and Ćirić et al. (2015) demonstrated that different types of supplementary feed (CG or PF and EF supplements) had no effect on water quality in carp ponds. In general, carp reduce water quality through bioturbation, i.e. physical disturbance of sediments during feeding activity, which remobilises and recycles nutrients (Matsuzaki et al. 2007, Adámek \& Maršálek 2013). This can lead to an increase in turbidity and higher chlorophyll $a$ and nutrient concentrations in the water column (Zambrano et al. 1998, Parkos et al. 2003), particularly phosphorus (Rahman et al. 2008). The intensity of these effects appears to be related, in part, to individual body size (Driver et al. 2005, Weber \& Brown 2009). Moreover, bioturbation appears to have a greater effect on nutrient concentration in the water than input of nutrients from feed (Hlaváč et al. 2015), despite feed generally representing the largest input of nutrients into fish ponds (Green \& Boyd 1995). Nevertheless, the high levels of organic matter resulting from primary production and, to a lesser extent, from feeding and fish excretion, do not necessarily constitute a source of pollution. In standing pond water, most organic matter is mineralised in situ. At the same time, natural processes ('self-purification') can remove potential pollutants from the water, including phosphorus (Steidl et al. 2008, Cereghino et al. 2014). Nutrient turnover in ponds is relatively quick, such that significant amounts tend not to remain in the water for long periods. Ponds with long hydraulic retention times display a longer response time to environmental change as nutrients are first stored in phytoplankton. For this reason, no significant short- term effects of management practice may be observed (Wezel et al. 2013), which may also explain the lack of any significant difference in water quality variables observed for all treatments in this study, including the control. Only conductivity appeared to be significantly affected by the PFLP feed, which could be explained by the higher concentration of calcium in artificial protein diets. This is in accordance with the study of Ćirić et al. (2015), who observed significantly higher mean hardness (and consequently conductivity) in ponds provided with $\mathrm{PF}$ rather than $\mathrm{CG}$, which they also attributed to a higher content of calcium.

Regarding natural food, although adult carp mainly ingest benthic macroinvertebrates, zooplankton, especially large-bodied organisms such as Daphnia, can also form a large part of the diet as the branchial sieve retains organisms $>0.25 \mathrm{~mm}$ (Sibbing et al. 1986, Rahman et al. 2009, Anton-Pardo et al. 2014). Carp occasionally reduce the abundance of largebodied zooplankton indirectly through increased turbidity, as high turbidity inhibits phytoplankton development and its ingestion by planktonic filter feeders. Alternatively, zooplankton abundance may be increased by nutrient input from the excretion of supplementary feed, which provides nutrients for phytoplankton growth (Moriarty 1997, Milstein et al. 2002). This is in accordance with the opinion of Billard (1999), who reported that phytoplankton and zooplankton were just as abundant in ponds where fish were fed with CG as where organic fertiliser was spread. It remains unclear, however, whether the resultant increase in zooplankton abundance is stronger than its reduction through fish predation (Schindler 1992, Khan et al. 2003). In our study, the addition of nutrients through supplementary feeding may have stimulated algal growth, although this response may have been masked through increased turbidity, which can inhibit zooplankton ingestion of phytoplankton. This is probably the reason why we found no differ- 
ence in zooplankton abundance between ponds with and without supplementary feeding and between treatments. On the other hand, Ćirić et al. (2015) found that the average abundance of zooplankton and macrozoobenthos was significantly higher in ponds where PF was added than in ponds with $\mathrm{CG}$ and EF. This could be explained by the 2 times higher protein level in the PF they used, which acted as a source of nutrients promoting the development of natural foods (Milstein 1992, Rahman et al. 2008).

Despite the uniform level of estimated digestible energy in the feeds used, better growth performance was observed in the CG and EF treatments compared with PF and PFLP. One probable reason for this was the physical quality of the feeds used. Urbánek et al. (2010) and Másílko et al. (2014) suggested that CG can provide valuable components for carp nutrition. Furthermore, CG are an easy and cheap source of digestible energy in the form of carbohydrates, especially starch (Gatlin et al. 2007), and are more resistant to nutrient leaching due to their strong hull, which is formed of insoluble, non-swelling materials such as cellulose (Hlaváč et al. 2014). Differences in the physical qualities of EF and PF have also been widely documented, with EF usually more stable in water than the PF (Hilton et al. 1981). This may explain our results for phosphorus budget, since all PF treatments showed a higher concentration of phosphorus in effluent water. A further advantage to feeding with CG in carp pond aquaculture is their resistance to nutrient leaching, unlike industrially produced PF mixtures (Másílko et al. 2014).

Fish themselves are important nutrient pools and can exert a major influence on the dynamics, distribution and ratio of limiting nutrients in freshwater ecosystems (Vanni 2002). Nutrient cycling by fish can supply phosphorus at rates comparable to major nutrient sources and can support a substantial proportion of the nutrient demands of primary producers (Brabrand et al. 1990, Persson 1997, Vanni 2002). Few data exist on the range of nutrient variation in fish bodies and its taxonomic, allometric or ecological correlates (Sterner \& George 2000, Tanner et al. 2000, Vanni 2002). Such data would improve model output and help to clarify the role of fish in nutrient cycles and budgets (Sterner \& George 2000, Dantas \& Attayde 2007). Fish body chemical content is species-specific (Sterner \& George 2000, Tanner et al. 2000, Griffiths 2006) and varies greatly throughout the year depending on a range of factors, including fish length and mass (Dantas \& Attayde 2007, Torres \& Vanni 2007). In our study, we found that content of dry matter and phosphorus was generally higher in harvested fish than in stocked fish. This is in accordance with the literature data (Shearer 1984, Deegan 1986, Torres \& Vanni 2007), which shows that phosphorus varies in a fish's body from early to later stages of growth. In our previous study (Hlaváč et al. 2016), we found that carp body phosphorus and nitrogen content varied from early to later stages of growth, with a noticeable increase in dry matter content during the growing season. Additionally, diet also has an influence on the chemical composition of fish, e.g. with mineral concentrations over the whole of the fish's body highly correlated with phosphorus level in the diet (Nwanna et al. 2008, 2010). In our study, phosphorus concentration in the fish's body was correlated with an increase in phosphorus in the diet, though high variability between samples meant that the correlations were not significant.

With respect to phosphorus budget, phosphorus retention was significantly higher in the control treatment with zero feed input than in CG and compound feed treatments, where phosphorus input from feed was higher. This corresponds with the results of Siddiqui \& Al-Harbi (1999) and Rahman et al. (2008), who reported increasing nutrient accumulation efficiency in fish with decreasing feed input. In ponds receiving protein-rich pellets, it has been shown that only 13 to $36 \%$ of phosphorus supplied is retained in fish biomass (Avnimelech \& Lacher 1979, Boyd 1985, Acosta-Nassar et al. 1994), a large fraction of the unused waste phosphorus accumulating in the sediment and affecting water quality in the overlaying water column. Our mean values for phosphorus retention (60-88\%) were higher than the above mentioned figures. Note, however, that the fish stocking densities quoted in those studies were much higher (>10000 ind. $\mathrm{ha}^{-1}$ ) than those commonly used in Czech carp ponds (100s ind. ha ${ }^{-1}$ ). The principal fate of uneaten artificial feed in ponds is decomposition of organic matter with consequent release of nutrients, which is supported by carp bioturbation activity. This in turn drives bacterial decomposition and primary production (Adámek \& Maršálek 2013). Stable isotope studies have indicated that most fish production in carp ponds is based on zooplankton and zoobenthos; and that even in pellet-fed ponds, 50 to $80 \%$ of fish production can originate from natural food (Schroeder 1983). Pond aquaculture, therefore, can benefit from improved strategies for natural food production and utilisation, which will also lead to reduced loading on the water environment.

In our study, we noted an unexplained source of phosphorus (ca. 20\%), possibly arising from sediment release and bioturbation, insects, dust, fallout 
and/or rainfall (Cole et al. 1990, Boyd 1995, Newman 1995, Kopáček et al. 1997, Holas et al. 1999). Even in closed recirculation systems, around 15 to $25 \%$ of the nutrient balance can remain unexplained (Verdegem 2007). Nevertheless, the CG and EF treatments produced the lowest phosphorus concentrations in effluent water. Physical quality of feed and reduced nutrient leaching probably played an important role in this aspect.

The financial sustainability of fish farming depends mainly on the market prices of products and inputs, and on production efficiency (Bosma \& Verdegem 2011). This involves a reduction in costs, along with an increase in production intensity and efficiency, disease control and significant investment in modern technology (Wedekind et al. 2001). The primary goal of rational pond management is to use existing conditions in the ponds to produce fish in order to maximise economic return to the farmer (Turkowski \& Lirski 2010). In the case of carp, it is of extreme importance that the feed type selected is able to achieve the most profitable production. In other words, improvement of semi-intensive systems is achieved through better quality of supplementary feed and improved feeding practices (Abdelghany \& Ahmad 2002). The sensitivity of fish production costs regarding yield has been well documented (Engle 2010) and, while changes in pond management practices can improve fish yield, this does not automatically mean that these practices are economically rentable (Omondi et al. 2001). In our study, we showed that supplementary feeding with an inappropriate type of feed could reduce farm profitability more than not using supplementary feeds at all.

\section{CONCLUSIONS}

The use of CG in semi-intensive monoculture ponds (stocked with $3 \mathrm{yr}$ old carp at a density of 363 fish $\mathrm{ha}^{-1}$ ) generated both economic and environmental benefits, compared with PF and EF treatments. Our results suggest that, for maximum efficiency of feed utilisation in carp pond aquaculture, CG probably represents the only option, both in terms of economic effects and the importance of sustainable water quality in ponds.

Acknowledgements. This study was supported financially by the Ministry of Education, Youth and Sports of the Czech Republic through Projects 'CENAKVA' (No. CZ.1.05/2.1.00/ 01.0024) and 'CENAKVA II' (No. LO1205 under the NPU I programme); Project CZ.1.07/2.3.00/30.0006 - for the Cre- ation of Post-doctorate Positions at the University of South Bohemia - Inter-sectional Mobility through Expert Stays at Leading Foreign R\&D Institutions; National Agency for Agricultural Research (Project No. QJ1510119) and Project Nos. 074/2013/Z and 060/2016/Z of the Grant Agency of the University of South Bohemia in Ceské Budějovice. We thank Rybářství Třeboň a.s. (Třeboň Fisheries Ltd.) for material and personnel support.

\section{LITERATURE CITED}

Abdelghany AE, Ahmad MH (2002) Effects of feeding rates on growth and production of Nile tilapia, common carp and silver carp polycultured in fertilized ponds. Aquacult Res 33:415-423

> Acosta-Nassar MV, Morell JM, Corredor JE (1994) The nitrogen budget of a tropical semi-intensive freshwater fish culture pond. J World Aquacult Soc 25:261-270

Adámek Z, Maršálek B (2013) Bioturbation of sediments by benthic macroinvertebrates and fish and its implication for pond ecosystems: a review. Aquacult Int 21:1-17

Adámek Z, Linhart $O$, Kratochvíl M, Flajšhans $M$ and others (2012) Aquaculture in the Czech Republic in 2012: modern European prosperous sector based on thousand-year history of pond culture. Aquacult Eur 37:5-14

Anton-Pardo M, Hlaváč D, Másílko J, Hartman P, Adámek Z (2014) Natural diet of mirror and scaly carp (Cyprinus carpio) phenotypes in earth ponds. Folia Zool 63:229-237

AOAC (Association of Official Analytical Chemists) (1995) Official methods of analysis, $16^{\text {th }}$ edn. AOAC, Arlington, VA

Avnimelech Y, Lacher M (1979) Tentative nutrient balance for intensive fish ponds. Bamidgeh 31:3-8

Barrows FT, Stone DAJ, Hardy RW (2007) The effects of extrusion conditions on the nutritional value of soybean meal for rainbow trout (Oncorhynchus mykiss). Aquaculture 265:244-252

Billard R (1999) Carp: biology and culture. Springer Praxis Publishing, Chichester

- Bosma RH, Verdegem MCJ (2011) Sustainable aquaculture in ponds: principles, practices and limits. Livest Sci 139: 58-68

Boyd CE (1985) Chemical budgets for channel catfish ponds. Trans Am Fish Soc 114:291-298

Boyd CE (1995) Bottom soils, sediment, and pond aquaculture. Chapman and Hall, New York, NY

> Brabrand A, Faafend BA, Nilssen JPM (1990) Relative importance of phosphorus supply to phytoplankton production: fish excretion versus external loading. Can J Fish Aquat Sci 47:364-372

- Cereghino R, Boix D, Cauchie HM, Martens K, Oertli B (2014) The ecological role of ponds in a changing world. Hydrobiologia 723:1-6

Chamberlain G, Rosenthal H (1995) Aquaculture in the next century. Opportunities for growth challenges of sustainability. World Aquacult 26:21-25

> Ćirić M, Subakov-Simić G, Dulić Z, Bjelanović K, Čičovački S, Marković Z (2015) Effect of supplemental feed type on water quality, plankton and benthos availability and carp (Cyprinus carpio L.) growth in semi-intensive monoculture ponds. Aquacult Res 46:777-788

> Cole JJ, Caraco NF, Likens GE (1990) Short-range atmospheric transport: a significant source of phosphorus to an oligotrophic lake. Limnol Oceanogr 35:1230-1237 
CSN 467092 (1998) Czech state standard, testing methods for feeding stuffs, Part 11 (Determination of total phosphorus content) and 12 (Determination of calcium content)

Dantas MC, Attayde JL (2007) Nitrogen and phosphorus content of some temperate and tropical freshwater fishes. J Fish Biol 70:100-108

> Deegan LA (1986) Changes in body-composition and morphology of young-of-the-year gulf menhaden, Brevoortia patronus Goode, in Fourleague Bay, Louisiana. J Fish Biol 29:403-415

Driver PD, Closs GP, Koen T (2005) The effects of size and density of carp (Cyprinus carpio L.) on water quality in an experimental pond. Arch Hydrobiol 163:117-131

Dulić Z, Subakov-Simić G, Ćirić M, Relić R, Lakić N, Stanković M, Marković Z (2010) Water quality in semiintensive carp production system using three different feeds. Bulg J Agric Sci 16:266-274

Engle CR (2010) Aquaculture economics and financing: management and analysis. Blackwell Scientific, Ames, IA

Gatlin DM III, Barrows FT, Brown P, Dabrowski K and others (2007) Expanding the utilization of sustainable plant products in aquafeeds: a review. Aquacult Res 38: 551-579

Green BW, Boyd CE (1995) Chemical budgets for organically fertilized fish ponds in the dry tropics. J World Aquacult Soc 26:284-296

- Griffiths D (2006) The direct contribution of fish to lake phosphorus cycles. Ecol Freshw Fish 15:86-95

Hardy RW, Barrows FT (2000) Diet formulation and manufacturing. In: Halver JE, Hardy RW (eds) Fish nutrition, 3rd edn. Academic Press, New York, NY, p 506-600

- Hilton JW, Cho CY, Slinger SJ (1981) Effect of extrusion processing and steam pelleting diets on pellet durability, pellet water absorption and the physiological response of rainbow trout (Salmo gairdneri). Aquaculture 25: 185-194

> Hlaváč D, Adámek Z, Hartman P, Másílko J (2014) Effects of supplementary feeding in carp ponds on discharge water quality: a review. Aquacult Int 22:299-320

> Hlaváč D, Másílko J, Hartman P, Bláha M, Pechar L, AntonPardo M, Adámek Z (2015) Effects of common carp (Cyprinus carpio L.) supplementary feeding with modified cereals on pond water quality and nutrient budget. J Appl Ichthyol 31:30-37

- Hlaváč D, Anton-Pardo M, Másílko M, Hartman P and others (2016) Supplementary feeding with thermally treated cereals in common carp (Cyprinus carpio L.) pond farming and its effects on water quality, nutrient budget and zooplankton and zoobenthos assemblages. Aquacult Int 24:1681-1697

> Holas J, Holas M, Chour V (1999) Pollution by phosphorus and nitrogen in water streams feeding the Zelivka drinking water reservoir. Water Sci Technol 39:207-214

> Hua K, Bureau DP (2010) Quantification of differences in digestibility of phosphorus among cyprinids, cichlids, and salmonids through a mathematical modelling approach. Aquaculture 308:152-158

> Jahan P, Watanabe T, Satoh S, Kiron V (2001) Formulation of low phosphorus loading diets for carp (Cyprinus carpio L.). Aquacult Res 32:361-368

Khan TA, Wilson ME, Khan M (2003) Evidence for invasive carp mediated trophic cascade in shallow lakes of western Victoria, Australia. Hydrobiologia 506-509:465-472

Kopáček J, Procházková L, Hejzlar J, Blažka P (1997) Trends and seasonal patterns of bulk deposition of nutrients in the Czech Republic. Atmos Environ 31:797-808

Lall SP (1991) Digestibility, metabolism and excretion of dietary phosphorus in fish. In: Cowey CB, Cho CY (eds) Nutritional strategies and aquaculture waste. Proceedings of the first international symposium on nutritional strategies in management of aquaculture Waste, Guelph, Ontario, Canada, 5-8 June, 1990, p 21-35

Marković Z, Poleksić V, Lakić N, Živić I and others (2012) Evaluation of growth and histology of liver and intestine in juvenile carp (Cyprinus carpio, L.) fed extruded diets with or without fish meal. Turk J Fish Aquat Sci 12: 301-308

Másílko J, Hartvich P, Rost M, Urbánek M, Hlaváč D, Dvořák P (2014) Potential for improvement of common carp production efficiency by mechanical processing of cereal diet. Turk J Fish Aquat Sci 14:145-153

Matsuzaki SS, Usio N, Takamura N, Washitani I (2007) Effects of common carp on nutrient dynamics and littoral community composition: roles of excretion and bioturbation. Fundam Appl Limnol 168:27-38

Mente E, Pierce GJ, Santos MB, Neofitou C (2006) Effect of feed and feeding in the culture of salmonids on the marine aquatic environment: a synthesis for European aquaculture. Aquacult Int 14:499-522

Milstein A (1992) Ecological aspects of fish species interactions in polyculture ponds. Hydrobiologia 231:177-186

Milstein A, Wahab MA, Rahman MM (2002) The effect of common carp Cyprinus carpio (L.) and mrigal Cirrhinus mrigala (Hamilton) as bottom feeders in major Indian carp polycultures. Aquacult Res 33:1103-1117

> Moriarty DJW (1997) The role of microorganisms in aquaculture ponds. Aquaculture 151:333-349

Mráz J, Máchová J, Kozák P, Picková J (2012) Lipid content and composition in common carp-optimization of n-3 fatty acids in different pond production systems. J Appl Ichthyol 28:238-244

> Naylor RL, Goldburg RJ, Primavera JH, Kautsky N and others (2000) Effect of aquaculture on world fisheries supplies. Nature 405:1017-1024

- Newman EI (1995) Phosphorus inputs to terrestrial ecosystems. J Ecol 83:713-726

Nwanna LC, Adebayo IA, Omitoyin B (2008) Effect of different levels of phosphorus on growth and mineralization in African giant catfish Heterobranchus bidorsalis (Geoffrey Saint Hillarie, 1809). J Appl Sci Environ Manag 12:25-32

> Nwanna LC, Kuhlwein H, Schwarz FJ (2010) Phosphorus requirement of common carp (Cyprinus carpio L.) based on growth and mineralization. Aquacult Res 41:401-410

> Omondi JG, Gichuri WM, Veverica K (2001) A partial economic analysis for Nile tilapia Oreochromis niloticus L. and sharptoothed catfish Clarias gariepinus (Burchell 1822) polyculture in central Kenya. Aquacult Res 32: 693-700

> Parkos JJ III, Santucci VJ Jr, Wahl DH (2003) Effects of common carp (Cyprinus carpio) on multiple trophic levels in shallow mesocosms. Can J Fish Aquat Sci 60:182-192

Persson A (1997) Phosphorus release by fish in relation to external and internal load in a eutrophic lake. Limnol Oceanogr 42:577-583

Rahman MM (2015) Effects of co-cultured common carp on nutrients and food web dynamics in rohu aquaculture ponds. Aquacult Environ Interact 6:223-232

- Rahman MM, Verdegem M, Nagelkerke L, Wahab MA, 
Milstein A, Verreth J (2008) Effects of common carp Cyprinus carpio (L) and feed addition in rohu Labeo rohita (Hamilton) ponds on nutrient partitioning among fish, plankton and benthos. Aquacult Res 39:85-95

Rahman MM, Hossain MY, Jo O, Kim SK, Ohtomi J, Meyer $\mathrm{C}$ (2009) Ontogenetic shift in dietary preference and low dietary overlap in rohu (Labeo rohita) and common carp (Cyprinus carpio) in semi-intensive polyculture ponds. Ichthyol Res 56:28-36

Rašković B, Jarić I, Koko V, Spasić M, Dulić Z, Marković Z, Poleksić V (2013) Histopathological indicators: a useful fish health monitoring tool in common carp (Cyprinus carpio Linnaeus, 1758) culture. Cent Eur J Biol 8:975-985

Rašković B, Čičovački S, Ćirić M, Marković Z, Poleksić V (2016) Integrative approach of histopathology and histomorphometry of common carp (Cyprinus carpio L.) organs as a marker of general fish health state in pond culture. Aquacult Res 47:3455-3463 doi:10.1111/are.12795

Satoh S, Hernández A, Tokoro T, Morishita Y, Kiron V, Watanabe T (2003) Comparison of phosphorus retention efficiency between rainbow trout (Oncorhynchus mykiss) fed a commercial diet and a low fish meal based diet. Aquaculture 224:271-282

Schindler DE (1992) Nutrient regeneration by sockeye salmon (Oncorhynchus nerka) fry and subsequent effects on zooplankton and phytoplankton. Can J Fish Aquat Sci 49:2498-2506

Schroeder GL (1983) The role of natural foods in tilapia growth: a study based on stable isotope analysis. In: Fishelson L, Yaron Z (eds) International symposium on tilapia in aquaculture, Nazareth, Israel, 8-13 May, 1983, p 313-322

Shearer KD (1984) Changes in elemental composition of hatchery-reared rainbow trout, Salmo gairdneri, associated with growth and reproduction. Can J Fish Aquat Sci 41:1592-1600

Sibbing FA, Osse JWM, Terlouw A (1986) Food handling in the carp (Cyprinus carpio): its movement patterns, mechanisms and limitations. J Zool 210:161-203

Siddiqui AQ, Al-Harbi AH (1999) Nutrient budgets in tanks with different stocking densities of hybrid tilapia. Aquaculture 170:245-252

Steffens W (1989) Principles of fish nutrition. Halsted Press, New York, NY

Steidl J, Kalettka T, Ehlert V, Quast J, Augustin J (2008) Mitigation of pressures on water bodies by nutrient retention from agricultural drainage effluents using purification ponds. Proceedings of the 10th international drainage workshop, Vol 16. Helsinki University of Technology, Helsinki, p 187-194

Sterner RW, George NB (2000) Carbon, nitrogen and phos-

Editorial responsibility: Catriona MacLeod,

Hobart, Tasmania, Australia phorus stoichiometry of cyprinid fishes. Ecology 81: $127-140$

Sugiura SH, Dong FM, Hardy RW (2000) A new approach to estimating the minimum dietary requirement of phosphorus for large rainbow trout based on nonfecal excretions of phosphorus and nitrogen. J Nutr 130:865-872

Tanner DK, Brazner JC, Brady VJ (2000) Factors influencing carbon, nitrogen and phosphorus content of fish from a Lake Superior coastal wetland. Can J Fish Aquat Sci 57: 1243-1251

Torres LE, Vanni MJ (2007) Stoichiometry of nutrient excretion by fish: interspecific variation in a hypereutrophic lake. Oikos 116:259-270

Trbović D, Marković Z, Milojković-Opsenica D, Petronijević R, Spirić D, Djinović-Stojanović J, Spirić A (2013) Influence of diet on proximate composition and fatty acid profile in common carp (Cyprinus carpio). J Food Compos Anal 31:75-81

Turkowski K, Lirski A (2010) The economics of carp farms in Poland. Acta Ichthyol Piscat 40:137-144

Urbánek M, Hartvich P, Vácha F, Rost M (2010) Investigation of fat content in market common carp (Cyprinus carpio) flesh during the growing season. Aquacult Nutr 16: 511-519

- Vanni MJ (2002) Nutrient cycling by animals in freshwater ecosystems. Annu Rev Ecol Syst 33:341-370

Verdegem MCJ (2007) Nutrient balances in ponds. In: van der Zijpp AJ, Verreth JAJ, Le Quang Tri, van Mensvoort MEF, Bosma RH, Beveridge MCM (eds) Fishponds in farming systems. Wageningen Academic Publishers, Wageningen, p 71-78

- Weber MJ, Brown ML (2009) Effects of common carp on aquatic ecosystems 80 years after 'Carp as a dominant': ecological insights for fisheries management. Rev Fish Sci 17:524-537

- Wedekind H, Hilge V, Steffens W (2001) Present status, and social and economic significance of inland fisheries in Germany. Fish Manag Ecol 8:405-414

Wezel A, Robin J, Guerin M, Arthaud F, Vallod D (2013) Management effects on water quality, sediments and fish production in extensive fish ponds in the Dombes region, France. Limnologica 43:210-218

Zambrano L, Perrow MR, Macias-Garcia C, AguirreHidalgo V (1998) Impact of introduced carp (Cyprinus carpio) in subtropical shallow ponds in Central Mexico. J Aquat Ecosyst Stress Recovery 6:281-288

Živić I, Živić M, Bjelanović K, Spasić M, Rašković B, Stanković M, Marković Z (2014) Fatty acid profile in muscles of carp (Cyprinus carpio L.) raised in a semiintensive production system fed with grains, pelleted and extruded feed. Arch Biol Sci 66:877-887

Submitted: May 30, 2016; Accepted: October 25, 2016

Proofs received from author(s): November 29, 2016 